\title{
Penetapan Kebutuhan Air Tanaman Cabai Merah (Capsicum annuum L.) dan Cabai Rawit (Capsicum frutescens L.)
}

\section{Crop Water Requirement Determination of Red Pepper (Capsicum annuum L.) and Cayenne Pepper (Capsicum frutescens $L$.}

\author{
Devie Rienzani Supriadi ${ }^{1 *}$, Anas D. Susila ${ }^{2}$, dan Eko Sulistyono ${ }^{2}$
}

Diterima 10 Agustus 2017/Disetujui 28 Februari 2018

\begin{abstract}
Crop production can not be separated from the management provided, such as cultivation techniques in determining of water requirements. Water availability determines the success of crop production, either vegetative or generative because water is a basic need for plants. This study was conducted from March to June 2016 in a greenhouse of Cikabayan Experimental Station, Bogor Agricultural University. It consisted of 2 sets of experiment. The first experiment used a red pepper (Capsicum annuum L.) and second experiment used a cayenne pepper (Capsicum frutescens L.). Each experiment was arranged in a single factor randomized block design (RBD) with irrigation level treatment $(V)$ consisted of 5 levels, i.e. $v_{1}=1 \mathrm{kc}$.Eo, $v_{2}=2 \mathrm{kc}$.Eo, $v_{3}=3 \mathrm{kc}$.Eo, $v_{4}=4 \mathrm{kc}$.Eo, and $v_{5}=5 \mathrm{kc}$.Eo. $k c$ is a plant coefficient and Eo is pan evaporation measured every two days before irrigation. The results showed that the response of red pepper (Capsicum annuum L.) and cayenne pepper (Capsicum frutescens $L$.$) on growth and production parameters were linear. The water$

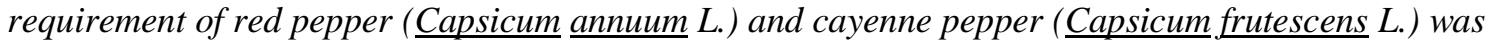
still higher than the highest irrigation level of treatment given in this experiment i.e. $5 \mathrm{kc}$. Eo.
\end{abstract}

Keywords: evapotranspiration, irrigation, number of flowers, plant coefficient, plant height

\begin{abstract}
ABSTRAK
Keberhasilan tanaman untuk berproduksi secara maksimal tidak terlepas dari pengelolaan yang diberikan seperti teknik budidaya dalam penetapan jumlah air yang dibutuhkan. Ketersediaan air menentukan keberhasilan produksi tanaman, baik secara vegetatif maupun generatif karena air merupakan kebutuhan dasar bagi tanaman. Percobaan ini dilaksanakan pada bulan Maret sampai Juni 2016, bertempat di rumah kaca Kebun Percobaan Cikabayan, Institut Pertanian Bogor. Penelitian ini terdiri atas 2 set percobaan, percobaan 1 menggunakan cabai merah (Capsicum annuиm L.) dan percobaan 2 menggunakan cabai rawit (Capsicum frutescens L.). Masing-masing percobaan menggunakan Rancangan Acak Kelompok (RAK) satu faktor perlakuan yaitu tingkat irigasi (V) yang terdiri atas 5 taraf, yaitu: $\mathrm{v}_{1}=1 \mathrm{kc}$.Eo, $\mathrm{v}_{2}=2 \mathrm{kc}$.Eo, $\mathrm{v}_{3}=3 \mathrm{kc}$.Eo, $\mathrm{v}_{4}=4 \mathrm{kc}$.Eo, dan $v_{5}=5 \mathrm{kc}$.Eo. kc adalah koefisien tanaman dan Eo adalah evaporasi panci yang diukur setiap dua hari sekali sebelum irigasi. Hasil percobaan menunjukkan bahwa respon tanaman cabai merah (Capsicum annuиm L.) dan cabai rawit (Capsicum frutescens L.) pada parameter pertumbuhan dan produksi merupakan respon linier. Kebutuhan air tanaman cabai merah (Capsicum annuum L.) dan cabai rawit (Capsicum frutescens L.) masih lebih tinggi dibandingkan dengan perlakuan tingkat irigasi tertinggi yang diberikan pada percobaan ini yaitu $5 \mathrm{kc}$.Eo.
\end{abstract}

Kata kunci: evapotranspirasi, irigasi, jumlah bunga, koefisien tanaman, tinggi tanaman

\footnotetext{
${ }^{1}$ Mahasiswa Pascasarjana, Departemen Agronomi dan Hortikultura, Fakultas Pertanian, Institut Pertanian Bogor

${ }^{2}$ Departemen Agronomi dan Hortikultura, Fakultas Pertanian, Institut Pertanian Bogor

J1. Meranti Kampus Darmaga, Bogor 16680 Indonesia.

Email: devierienzani@gmail.com (*Penulis korespondensi)
} 


\section{PENDAHULUAN}

Cabai merupakan komoditas potensial yang memiliki nilai ekonomi tinggi dan berpotensi untuk terus dikembangkan. Dirjen Hortikultura (2015) menyatakan beberapa alasan penting dalam pengembangan komoditas cabai, antara lain merupakan komoditas unggulan bernilai ekonomi tinggi, banyak digunakan untuk konsumsi rumah tangga (80\%) maupun keperluan industri pengolahan makanan (20\%). Loizzo et al. (2015) melaporkan bahwa cabai memiliki aktivitas antioksidan, kandungan fenol dan capsaicinoid yang tinggi. Terdapat dua jenis tanaman cabai yang umumnya dibudidayakan di Indonesia yaitu, cabai merah besar (Capsicum annuum L.) dan cabai rawit (Capsicum frutescens L.). Menurut FAOSTAT (2015) Indonesia menduduki peringkat ke empat sebagai negara dengan produksi cabai tertinggi di dunia setelah China, Mexico dan Turki, sedangkan angka produktivitasnya masih lebih rendah dibandingkan negara China yang mencapai 21.89 ton $\mathrm{ha}^{-1}$.

Ketersediaan air menentukan

keberhasilan produksi tanaman, baik secara vegetatif maupun generatif karena air merupakan kebutuhan dasar bagi tanaman. Kebutuhan air meningkat dengan meningkatnya kadar air tanah, tetapi efisiensi pemakaian air tertinggi pada kadar air tanah antara 55-70\% kapasitas lapang (Juan-juan et al., 2012). Kekurangan atau kelebihan air pada tanaman akan mempengaruhi pertumbuhan serta produksinya (Kurnia, 2004). Menurut Gonzalez et al. (2007), tanaman cabai sensitif dengan kekurangan air karena sistem perakarannya dangkal.

Kebutuhan air tanaman dapat ditentukan berdasarkan koefisien tanaman $(\mathrm{kc})$ dan evapotranspirasi referens (ETo). Evapotranspirasi referens dapat dihitung berdasarkan koefisien panci (Kp) dan evaporasi panci (Eo). Nilai koefisien tanaman berbeda-beda setiap fase tumbuh tanaman dan setiap tanaman. Nilai koefisien panci (Kp) berkisar antara 0.60.9 (Allen et al., 1998). Koefisien tanaman (kc) pada awal pertumbuhan paling rendah dan mencapai maksimal pada saat pembungaan atau pembuahan, kemudian berkurang menjelang fase pemasakan. Pada fase pertumbuhan tanaman maksimal (pembungaan atau pembuahan) dibutuhkan air dalam jumlah yang cukup banyak (Miranda et al., 2006). Oleh karena itu, fase-fase pertumbuhan tanaman, lamanya setiap fase pertumbuhan dan fase kritis pertumbuhan perlu diketahui agar perencanaan pemberian air, baik jumlah maupun waktunya lebih tepat. Liu et al. (2012) menyatakan kebutuhan air bagi tanaman adalah sama dengan evapotranspirasi.

Hasil penelitian Sulistiyono dan Juliana (2014) menunjukkan bahwa untuk mengetahui volume irigasi tanaman didasarkan pada evaporasi panci (Eo), sehingga diketahui jumlah air yang akan digunakan berdasarkan perlakuan irigasinya. Penelitian ini penting dilakukan untuk mengatasi gangguan proses produksi tanaman cabai yang berhubungan dengan kebutuhan air. Tujuan penelitian ini ialah untuk mendapatkan kebutuhan air optimal pada pertumbuhan dan produksi cabai merah (Capsicum annuum L.) dan cabai rawit (Capsicum frutescens L.).

\section{BAHAN DAN METODE}

\section{Waktu dan Tempat}

Penelitian dilaksanakan pada bulan Maret sampai Juni 2016, bertempat di rumah kaca kebun percobaan Cikabayan, Institut Pertanian Bogor. Analisis komponen produksi dan kadar air tanah dilakukan di Laboratorium Pascapanen Departemen Agronomi dan Hortikultura, analisis fisika tanah di Laboratorium Kimia dan Fisika Tanah Departemen Ilmu dan Sumberdaya Lahan, analisis tanah dan pupuk kandang di Laboratorium Pengujian Fakultas Pertanian, Institut Pertanian Bogor.

\section{Kondisi Suhu dan Kelembaban Udara}

Suhu dan kelembaban udara diamati setiap hari dalam rumah kaca dengan menggunakan termometer digital (maksimum minimum). Rata-rata suhu maksimum pada bulan April, Mei dan Juni masing-masing adalah $43{ }^{0} \mathrm{C}, 43{ }^{\circ} \mathrm{C}$ dan $43{ }^{\circ} \mathrm{C}$. Rata-rata kelembaban udara maksimum pada bulan April, Mei dan Juni adalah 88.9\%, 89.9\% dan $88.7 \%$. Kondisi suhu dan kelembaban udara dalam rumah kaca pada saat penelitian cukup tinggi, untuk menekan suhu yang terlalu tinggi digunakan blower dalam rumah kaca. 


\section{Prosedur Percobaan}

Penelitian ini terdiri atas 2 set percobaan, percobaan 1 menggunakan cabai merah (Capsicum annuum L.) dan percobaan 2 mengunakan cabai rawit (Capsicum frutescens L.). Masing-masing percobaan menggunakan Rancangan Acak Kelompok (RAK) satu faktor perlakuan yaitu tingkat irigasi $(\mathrm{V})$ yang terdiri atas 5 taraf, yaitu: $\mathrm{v}_{1}=1 \mathrm{kc}$.Eo, $\mathrm{v}_{2}=2 \mathrm{kc}$.Eo, $\mathrm{v}_{3}=3 \mathrm{kc}$. Eo, $\mathrm{v}_{4}=4 \mathrm{kc}$. Eo, dan $\mathrm{v}_{5}=5 \mathrm{kc}$.Eo. kc adalah koefisien tanaman dan Eo adalah evaporasi panci yang diukur setiap dua hari sekali sebelum irigasi. Masing-masing percobaan diulang 4 kali dan setiap satuan percobaan terdiri atas 3 tanaman.

Perlakuan volume irigasi berdasarkan besarnya evaporasi dari permukaan air bebas yang diukur dengan panci penguapan menggunakan alat drum dengan diameter 57 $\mathrm{cm}$ dan tinggi $42 \mathrm{~cm}$ yang diisi air setinggi 400 mm. Nilai Eo didapatkan dengan mengukur selisih tinggi air yang berkurang di dalam panci pada pukul 07.00 pagi setiap dua hari sekali. Pengurangan tinggi air merupakan nilai Eo yang akan dikalikan dengan 5 konstanta yang berbeda $(1,2,3,4$ dan 5). Kemudian nilai tersebut dikalikan dengan luas permukaan polibag dan koefisien tanaman (kc) pada setiap fase yang berbeda, maka akan didapat volume air yang diberikan berdasarkan masing-masing perlakuan (Sulistyono dan Juliana, 2014). Nilai kc tanaman cabai adalah $0.4,0.75,1.1,1$ dan 0.9. Masing-masing untuk umur tanaman awal, vegetatif, pembungaan, pembuahan, dan pemasakan (Doorenbos dan Kassam, 1979). Berdasarkan Tabel 1 dapat diketahui volume irigasi yang diberikan setiap hari, yaitu dengan mengalikan nilai konstanta, kc, Eo, dan luas polibag (contohnya: 1 x kc x 0.1Eo x luas polibag).

Tabel 1. Perhitungan kebutuhan volume air irigasi tiap perlakuan

\begin{tabular}{|c|c|c|c|c|c|}
\hline \multirow{3}{*}{ Komponen } & 1 & 2 & $3-4$ & $5-9$ & $10-15$ \\
\hline & \multicolumn{5}{|c|}{ Umur Tanaman (MST) } \\
\hline & Awal & Vegetatif & Pembungaan & Pembuahan & Pemasakan \\
\hline Nilai Konstanta & $1-5$ & $1-5$ & $1-5$ & $1-5$ & $1-5$ \\
\hline Kc (cabai) & 0.4 & 0.75 & 1.1 & 1 & 0.9 \\
\hline Eo $\left(m m\right.$ hari $\left.^{-1}\right)$ & Eo harian & Eo harian & Eo harian & Eo harian & Eo harian \\
\hline Luas Polibag $\left(\mathrm{cm}^{2}\right)$ & 1146.5 & 1146.5 & 1146.5 & 1146.5 & 1146.5 \\
\hline Volume Irigasi (ml) & - & - & - & - & - \\
\hline $\mathrm{v}_{1}$ & 458.6 Eo & 859.8 Eo & 1261.2 Eo & 1146.5 Eo & 1031.8 Eo \\
\hline $\mathrm{v}_{2}$ & 917.2 Eo & 1719.7 Eo & 2522.3 Eo & 2293.0 Eo & 2063.7 Eo \\
\hline $\mathrm{v}_{3}$ & $1375.8 \mathrm{Eo}$ & $2579.6 \mathrm{Eo}$ & 3783.5 Eo & 3439.5 Eo & 3095.5 Eo \\
\hline $\mathrm{V}_{4}$ & 1834.4 Eo & 3439.5 Eo & 5044.6 Eo & 4586.0 Eo & 4 127.4 Eo \\
\hline $\mathrm{V}_{5}$ & 2293.0 Eo & 4299.3 Eo & 6305.8 Eo & 5732.5 Eo & 5159.2 Eo \\
\hline
\end{tabular}

Tabel 2. Dosis pupuk pada setiap perlakuan volume irigasi dan setiap fase tumbuh tanaman

\begin{tabular}{|c|c|c|c|c|c|}
\hline \multirow{3}{*}{$\begin{array}{l}\text { Volume } \\
\text { Irigasi } \\
(\mathrm{ml})\end{array}$} & 1 & 2 & $3-4$ & $5-9$ & $10-15$ \\
\hline & \multicolumn{5}{|c|}{ Umur Tanaman (MST) } \\
\hline & Awal & Vegetatif & Pembungaan & Pembuahan & Pemasakan \\
\hline \multirow[t]{2}{*}{$\mathrm{V}_{1}$} & 458.6 & 859.8 & 1261.2 & 1146.5 & 1031.8 \\
\hline & Eo+NPK & Eo+NPK & Eo+NPK & Eo+NPK & Eo+NPK \\
\hline \multirow[t]{2}{*}{$\mathrm{V}_{2}$} & 917.2 & 1719.7 & 2522.3 & 2293 & 2063.7 \\
\hline & Eo+NPK & Eo+NPK & $\mathrm{Eo}+\mathrm{NPK}$ & Eo+NPK & Eo+NPK \\
\hline \multirow[t]{2}{*}{$\mathrm{V}_{3}$} & 1375.8 & 2579.6 & 3783.5 & 3439.5 & 3095.5 \\
\hline & Eo+NPK & Eo+NPK & $\mathrm{Eo}+\mathrm{NPK}$ & Eo+NPK & Eo+NPK \\
\hline \multirow[t]{2}{*}{$\mathrm{V}_{4}$} & 1834.4 & 3439.5 & 5044.6 & 4586 & 4127.4 \\
\hline & Eo+NPK & Eo+NPK & $\mathrm{Eo}+\mathrm{NPK}$ & Eo+NPK & Eo+NPK \\
\hline \multirow[t]{2}{*}{$\mathrm{V}_{5}$} & 2293 & 4299.3 & 6305.8 & 5732.5 & 5159.2 \\
\hline & Eo+NPK & Eo+NPK & Eo+NPK & Eo+NPK & Eo+NPK \\
\hline
\end{tabular}


Pemupukan dilakukan bersamaan dengan penyiraman atau pemberian volume irigasi. Pupuk NPK $\left(15 \% \mathrm{~N}, 15 \% \mathrm{P}_{2} \mathrm{O}_{5}, 15 \%\right.$ $\mathrm{K}_{2} \mathrm{O}$ ) diberikandengankonsentrasi $2 \mathrm{~g}$ NPK per liter air (setara dengan $300 \mathrm{ppm} \mathrm{N}, \mathrm{P}_{2} \mathrm{O}_{5}, \mathrm{~K}_{2} \mathrm{O}$ ). Pupuk dilarutkan dalam wadah berdasarkan konsentrasi tersebut, kemudian diaplikasikan sesuai dengan perlakuan volume irigasi.

\section{HASIL DAN PEMBAHASAN}

\section{Cabai Merah}

\section{Tinggi Tanaman}

Hasil analisis ragam menunjukkan bahwa tingkat irigasi berpengaruh nyata terhadap tinggi tanaman pada umur 3, 4, 5 dan 6 MST tetapi pada umur 1, 2 dan 7 MST tidak berbeda nyata. Tingkat irigasi memberikan respon linier terhadap tinggi tanaman pada umur 3, 4, 5 dan 6 MST (Tabel 3). Pola respon tinggi tanaman terhadap tingkat irigasi pada umur tanaman 3, 4, 5 dan 6 MST masingmasing adalah $\mathrm{y}=1.924 \mathrm{x}+22.91, \mathrm{y}=3.762 \mathrm{x}$ $+30.24, y=4.387 \mathrm{x}+33.189$ dan $\mathrm{y}=3.825 \mathrm{x}+$ 43.275, hal ini menunjukkan penambahan tingkat irigasi sampai $\mathrm{kc}$ x 5 Eo masih meningkatkan tinggi tanaman. Sulistyono dan Indriati (2011) menyatakan bahwa tinggi tanaman tertinggi dihasilkan oleh irigasi 2 hari sekali sampai $100 \%$ air tersedia (100\% AT) mulai dari saat tanam sampai panen pada tanaman kencur. Fauziah et al. (2016) melaporkan pemberian air $100 \%$ ETc atau konvensional meningkatkan tinggi tanaman dan jumlah daun segar.

Efisiensi pemakaian air lebih tinggi diperoleh pada irigasi sebesar $0.5 \mathrm{Eo}$, tingkat irigasi ini sudah mencukupi kebutuhan air tanaman cabai merah (Rameswaran et al., 2016). Penelitian tersebut berbeda dengan hasil penelitian ini karena sistem irigasinya berbeda. Irigasi drip pada penelitian tersebut kebutuhan airnya lebih rendah dibandingan dengan penelitian ini yang menggunakan irigasi permukaan yang membasahi seluruh permukaan lahan.

\section{Jumlah Cabang Vegetatif}

Berdasarkan hasil analisis ragam menunjukkan bahwa tingkat irigasi berpengaruh nyata terhadap jumlah cabang vegetatif pada umur tanaman 4 MST, tetapi pada umur 3 MST tidak berbeda nyata (Tabel 4). Tingkat irigasi memberikan respon linier terhadap jumlah cabang vegetatif pada umur 4 MST dengan pola respon $\mathrm{y}=1.508 \mathrm{x}+1.51$, artinya penambahan tingkat irigasi sampai $\mathrm{kc} x$ 5 Eo masih meningkatkan jumlah cabang vegetatif.

Tabel 3. Pertumbuhan tinggi tanaman $(\mathrm{cm})$ cabai merah pada berbagai tingkat irigasi

\begin{tabular}{cccccccc}
\hline Tingkat & \multicolumn{7}{c}{ Umur Tanaman $(\mathrm{MST})$} \\
\cline { 2 - 8 } Irigasi & 1 & 2 & 3 & 4 & 5 & 6 & 7 \\
\hline kc x 1 Eo & 12.35 & 17.94 & 24.58 & 32.59 & 35.25 & 42.63 & 45.50 \\
kc x 2 Eo & 12.72 & 18.88 & 28.30 & 41.33 & 45.96 & 55.88 & 58.63 \\
kc x 3 Eo & 12.14 & 18.13 & 25.83 & 37.38 & 43.13 & 54.25 & 57.00 \\
kc x 4 Eo & 13.63 & 21.17 & 32.71 & 48.54 & 54.50 & 62.63 & 63.13 \\
kc x 5 Eo & 12.91 & 20.23 & 32.00 & 47.79 & 52.92 & 58.38 & 62.00 \\
\hline Uji F & tn & tn & $*$ & $* *$ & $* *$ & $*$ & tn \\
\hline Respon & tn & tn & $\mathrm{L}^{*}$ & $\mathrm{~L} * *$ & $\mathrm{~L}^{* *}$ & $\mathrm{~L}^{*}$ & tn \\
\hline Keterangan: L $=$ linier, tn $=$ tidak nyata, $\left.{ }^{*}\right)=$ berbeda nyata pada $\left.(\mathrm{P} \leq 0.05), * *\right)=$ berbeda nyata pada $(\mathrm{P} \leq 0.01)$.
\end{tabular}

Tabel 4. Pertumbuhan jumlah cabang vegetatif cabai merah pada berbagai tingkat irigasi

\begin{tabular}{lccc}
\hline & Tingkat & \multicolumn{2}{c}{ Umur Tanaman (MST) } \\
\cline { 2 - 4 } Irigasi & 3 & 4 \\
\hline kc x 1 Eo & 0.17 & 1.67 \\
kc x 2 Eo & 0.67 & 5.49 \\
& kc x 3 Eo & 0.50 & 3.00 \\
& kc x 4 Eo & 1.33 & 7.08 \\
& kc x 5 Eo & 1.17 & 6.17 \\
\hline Uji F & & tn & $*$ \\
\hline Respon & & tn & $\mathrm{L}^{*}$ \\
\hline
\end{tabular}

Keterangan: $\mathrm{L}=$ linier, $\mathrm{tn}=$ tidak nyata, $*)=$ berbeda nyata pada $(\mathrm{P} \leq 0.05)$. 
Penelitian Antony dan Singandhupe (2004) menunjukkan perlakuan irigasi permukaan $100 \%$ pada tanaman cabai berpengaruh terhadap morfologi tanaman yaitu jumlah cabang, tinggi tanaman, panjang akar dan hasil panen. Penelitian Alviana dan Susila (2009) juga menunjukkan pertumbuhan vegetatif tanaman cabai yang ditanam dengan irigasi tetes dan mulsa polyethylene meningkat secara linier.

\section{Jumlah Bunga}

Hasil penelitian menunjukkan bahwa tingkat irigasi berpengaruh nyata terhadap jumlah bunga pada umur tanaman 6,7 dan 8 MST (Tabel 5). Tingkat irigasi memberikan respon linier terhadap jumlah bunga pada umur 6, 7 dan 8 MST dengan pola respon masing-masing adalah $\mathrm{y}=1.275 \mathrm{x}+0.475, \mathrm{y}=$ $2.075 \mathrm{x}-1.6$ dan $\mathrm{y}=2.1 \mathrm{x}-2.075$, hal ini menunjukkan penambahan tingkat irigasi sampai kc x 5 Eo masih meningkatkan jumlah bunga.

Gonzalez et al. (2007) menyatakan irigasi sangat penting untuk produksi cabai karena sebagai salah satu tanaman hortikultura yang paling rentan terhadap kekurangan air. Pada fase berbunga dan perkembangan buah merupakan fase yang paling sensitif terhadap kekurangan air. Pada saat pematangan buah sampai dengan panen tanaman cabai harus cukup air agar menghasilkan produksi maksimal. Bobot segar dan bobot kering buah cabai berkorelasi positif dengan jumlah air yang diberikan. Berdasarkan tingkat warna pada buah cabai merah, perlakuan T3 (480 $\mathrm{mm})$ memberikan hasil terbaik dibandingkan perlakuan lainnya T1 $(456 \mathrm{~mm})$ dan T2 (346 $\mathrm{mm})$. Penjadwalan irigasi yang tepat diperlukan untuk mencapai ukuran kanopi agar hasil optimal.

\section{Bobot Buah per Tanaman dan Bobot per Buah}

Tingkat irigasi berpengaruh nyata terhadap bobot buah per tanaman, tetapi pada bobot per buah tidak berbeda nyata. Tingkat irigasi memberikan respon linier terhadap bobot buah per tanaman. Gambar 1 menunjukkan pengaruh tingkat irigasi terhadap bobot buah per tanaman pada cabai merah dan pola responnya adalah $\mathrm{y}=2.51 \mathrm{x}-3.16$, artinya penambahan tingkat irigasi sampai kc x 5 Eo masih meningkatkan bobot buah per tanaman. Ucan et al. (2007) menyatakan bahwa jumlah air irigasi berpengaruh nyata terhadap produksi tanaman wijen. Banyak penelitian melaporkan bahwa total hasil buah cabai berkurang pada kondisi kekeringan (Cafer et al., 2006).

Tabel 5. Jumlah bunga cabai merah pada berbagai tingkat irigasi

\begin{tabular}{cccc}
\hline Tingkat & \multicolumn{3}{c}{ Umur Tanaman (MST) } \\
\cline { 2 - 4 } Irigasi & 6 & 7 & 8 \\
\hline kc x 1 Eo & 1.75 & 1.75 & 0.75 \\
kc x 2 Eo & 2.88 & 2.63 & 3.38 \\
kc x 3 Eo & 4.50 & 1.88 & 1.38 \\
kc x 4 Eo & 5.63 & 6.88 & 5.38 \\
kc x 5 Eo & 6.75 & 10.00 & 10.25 \\
\hline Uji F & $*$ & $* *$ & $* *$ \\
\hline Respon & $\mathrm{L}^{* *}$ & $\mathrm{~L}^{* *}$ & $\mathrm{~L}^{* *}$ \\
\hline
\end{tabular}

Keterangan: $\mathrm{L}=$ linier, $\left.{ }^{*}\right)=$ berbeda nyata pada $\left.(\mathrm{P} \leq 0.05),{ }^{* *}\right)=$ berbeda nyata pada $(\mathrm{P} \leq 0.01)$.

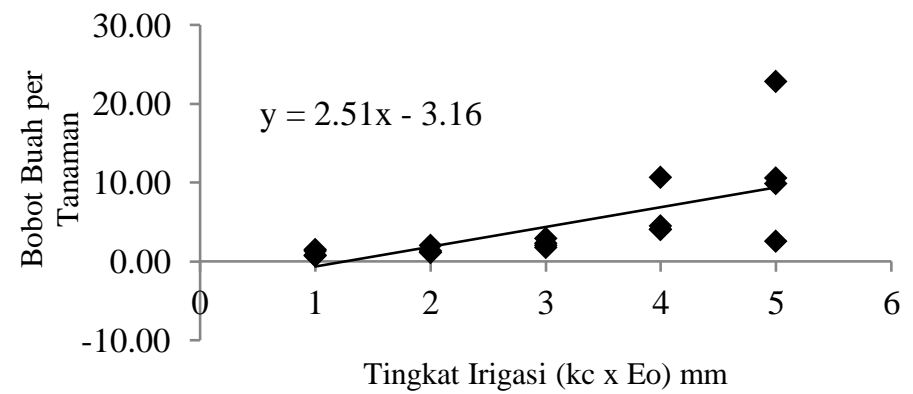

Gambar 1. Pengaruh tingkat irigasi terhadap bobot buah per tanaman pada cabai merah. 


\section{Cabai Rawit}

\section{Tinggi Tanaman}

Tingkat irigasi berpengaruh nyata terhadap tinggi tanaman pada umur 3, 4, 5, 6 dan 7 MST tetapi pada umur 1 dan 2 MST tidak berbeda nyata (Tabel 6). Hal ini diduga karena pada umur tanaman 1 dan 2 MST kebutuhan air tanaman masih rendah, sehingga belum menampakkan perbedaan yang nyata terhadap tinggi tanaman. Tingkat irigasi memberikan respon linier terhadap tinggi tanaman pada umur $3,4,5,6$ dan 7 MST dengan pola respon masingmasing adalah $\mathrm{y}=1.466 \mathrm{x}+19.12, \mathrm{y}=2.966 \mathrm{x}+$ $25.34, y=3.233 \mathrm{x}+30.616, \mathrm{y}=3.268 \mathrm{x}+35.556$ dan $\mathrm{y}=2.762 \mathrm{x}+39.28$. Hal ini menunjukkan bahwa penambahan tingkat irigasi sampai kc x 5 Eo masih meningkatkan tinggi tanaman.

\section{Jumlah Cabang Generatif}

Tabel 7 menunjukkan tingkat irigasi berpengaruh nyata terhadap jumlah cabang generatif pada umur 5, 6 dan 7 MST. Tingkat irigasi memberikan respon linier terhadap jumlah cabang generatif pada umur 5, 6 dan 7 MST. Pola respon jumlah cabang generatif terhadap tingkat irigasi pada umur 5, 6 dan 7 MST masing-masing adalah $\mathrm{y}=8.607 \mathrm{x}-0.006, \mathrm{y}=13.5 \mathrm{x}+23.95$ dan $y=27.475 x+26.45$ artinya penambahan tingkat irigasi sampai kc x 5 Eo masih meningkatkan jumlah cabang generatif. Shongwe et al. (2010) menyatakan peningkatan jumlah cabang tanaman akan berpengaruh terhadap munculnya bunga sehingga banyaknya jumlah cabang produktif dapat menghasilkan jumlah bunga dan buah yang lebih banyak.

\section{Jumlah Buah}

Tingkat irigasi berpengaruh nyata terhadap jumlah buah pada umur tanaman 9 MST dan panen, tetapi pada umur 8 MST tidak berbeda nyata. Tingkat irigasi memberikan respon kuadratik terhadap jumlah buah 9 MST dan panen (Tabel 8). Gambar 2 menunjukkan pengaruh tingkat irigasi terhadap jumlah buah cabai rawit pada umur 9 MST dan panen dengan pola respon masing-masing adalah $\mathrm{y}=0.529 \mathrm{x}^{2}-2.525 \mathrm{x}+$ 3.843 dan $\mathrm{y}=0.821 \mathrm{x}^{2}-3.336 \mathrm{x}+3.666$. Tingkat irigasi minimum pada umur 9 MST adalah $\mathrm{kc} x$ 2.38 Eo, artinya tingkat irigasi dari kc $\times 1$ Eo sampai kc x 2.38 Eo menyebabkan penurunan jumlah buah sedangkan tingkat irigasi lebih tinggi dari kc x 2.38 Eo menyebabkan peningkatan jumlah buah. Tingkat irigasi pada saat panen adalah kc x 2.03 Eo, hal ini menyatakan tingkat irigasi dari kc x 1 Eo sampai kc x 2.03 Eo menyebabkan penurunan jumlah buah sedangkan tingkat irigasi lebih tinggi dari $\mathrm{kc} \times 2.03$ Eo menyebabkan peningkatan jumlah buah.

Tabel 6. Pertumbuhan tinggi tanaman $(\mathrm{cm})$ cabai rawit pada berbagai tingkat irigasi

\begin{tabular}{cccccccc}
\hline Tingkat & \multicolumn{7}{c}{ Umur Tanaman (MST) } \\
\cline { 2 - 8 } Irigasi & 1 & 2 & 3 & 4 & 5 & 6 & 7 \\
\hline kc x 1 Eo & 11.49 & 14.98 & 20.54 & 27.63 & 33.13 & 39.25 & 42.63 \\
kc x 2 Eo & 11.60 & 15.75 & 21.96 & 31.92 & 37.04 & 41.13 & 43.38 \\
kc x 3 Eo & 11.64 & 15.87 & 23.71 & 34.67 & 41.75 & 46.13 & 49.00 \\
kc x 4 Eo & 10.95 & 16.67 & 25.13 & 37.25 & 43.71 & 48.31 & 49.50 \\
kc x 5 Eo & 11.88 & 17.30 & 26.29 & 39.79 & 45.96 & 52.00 & 53.38 \\
\hline Uji F & tn & tn & $* *$ & $* *$ & $* *$ & $*$ & $* *$ \\
\hline Respon & tn & tn & L** & L** & L** & L** & L**
\end{tabular}

Keterangan: $\mathrm{L}=$ linier, $\mathrm{tn}=$ tidak nyata, $\left.{ }^{*}\right)=$ berbeda nyata pada $\left.(\mathrm{P} \leq 0.05),{ }^{* *}\right)=$ berbeda nyata pada $(\mathrm{P} \leq 0.01)$.

Tabel 7. Pertumbuhan jumlah cabang generatif cabai rawit pada berbagai tingkat irigasi

\begin{tabular}{cccc}
\hline Tingkat & \multicolumn{3}{c}{ Umur Tanaman (MST) } \\
\cline { 2 - 4 } Irigasi & 5 & 6 & 7 \\
\hline kc x 1 Eo & 8.67 & 34.75 & 47.88 \\
kc x 2 Eo & 17.50 & 48.75 & 85.75 \\
kc x 3 Eo & 22.67 & 69.25 & 113.75 \\
kc x 4 Eo & 39.58 & 85.75 & 137.75 \\
kc x 5 Eo & 40.67 & 83.75 & 159.25 \\
\hline Uji F & $* *$ & $* *$ & $* *$ \\
\hline Respon & L** & L** & L** \\
\hline
\end{tabular}

Keterangan: $\mathrm{L}=$ linier, $\left.{ }^{* *}\right)=$ berbeda nyata pada $(\mathrm{P} \leq 0.01)$. 
Tabel 8. Jumlah buah cabai rawit pada berbagai tingkat irigasi

\begin{tabular}{cccc}
\hline Tingkat & \multicolumn{3}{c}{ Umur Tanaman (MST) } \\
\cline { 2 - 4 } Irigasi & 8 & 9 & Panen \\
\hline kc x 1 Eo & 1.46 & 1.75 & 0.79 \\
kc x 2 Eo & 0.83 & 1.09 & 0.99 \\
kc x 3 Eo & 1.08 & 1.08 & 1.04 \\
kc x 4 Eo & 1.71 & 1.96 & 2.75 \\
kc x 5 Eo & 3.00 & 4.56 & 7.88 \\
\hline Uji F & tn & $*$ & $* *$ \\
\hline Respon & tn & $\mathrm{Q}^{* *}$ & $\mathrm{Q}^{* *}$
\end{tabular}

Keterangan: $\mathrm{Q}=$ kuadratik, $\mathrm{tn}=$ tidak nyata, $\left.{ }^{*}\right)=$ berbeda nyata pada $\left.(\mathrm{P} \leq 0.05),{ }^{* *}\right)=$ berbeda nyata pada $(\mathrm{P} \leq 0.01)$.

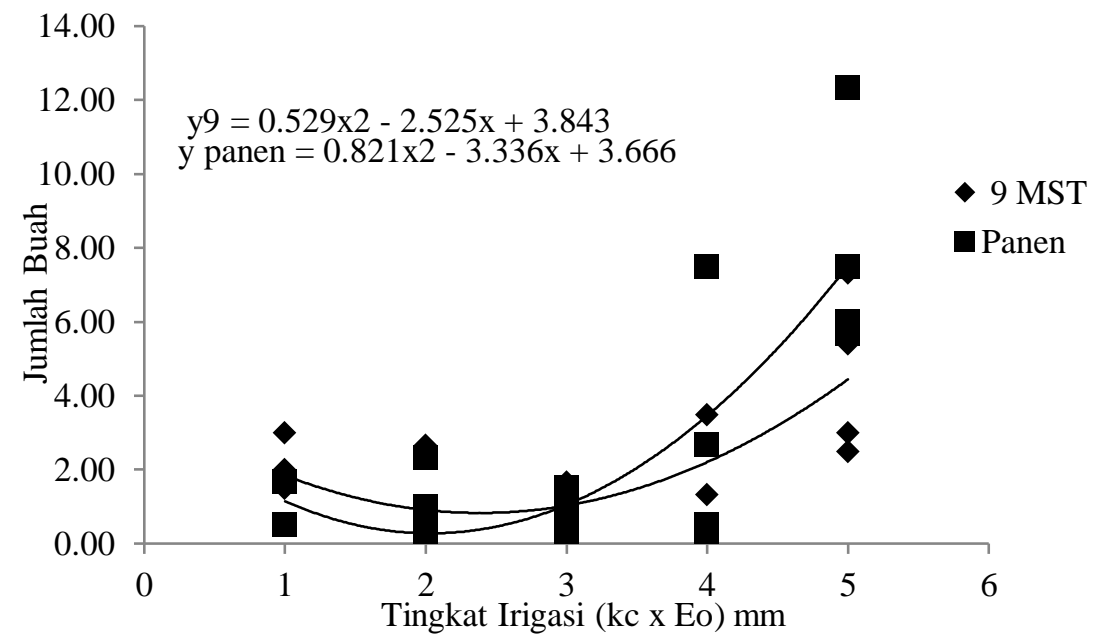

Gambar 2. Pengaruh tingkat irigasi terhadap jumlah buah cabai rawit pada umur 9 MST dan panen.

Tabel 9. Bobot buah per tanaman dan bobot per buah cabai rawit pada berbagai tingkat irigasi

\begin{tabular}{rcc}
\hline $\begin{array}{c}\text { Tingkat } \\
\text { Irigasi }\end{array}$ & $\begin{array}{c}\text { Bobot Buah per Tanaman } \\
(\mathrm{g})\end{array}$ & $\begin{array}{c}\text { Bobot per Buah } \\
(\mathrm{g})\end{array}$ \\
\hline kc x 1 Eo & 1.65 & 2.62 \\
kc x 2 Eo & 1.25 & 1.63 \\
kc x 3 Eo & 1.40 & 1.71 \\
kc x 4 Eo & 2.31 & 2.42 \\
kc x 5 Eo & 2.15 & 0.29 \\
\hline Uji F & tn & tn \\
\hline Respon & tn & tn
\end{tabular}

\section{Bobot Buah per Tanaman dan Bobot per Buah}

Tabel 9 menunjukkan tingkat irigasi tidak berpengaruh nyata terhadap bobot buah per tanaman dan bobot per buah pada cabai rawit. Berdasarkan pengamatan di lapangan, jika jumlah buah sedikit maka ukuran buahnya lebih besar dan sebaliknya jika jumlah buah banyak maka ukuran buahnya keci. Hal tersebut diduga menyebabkan bobot buah per tanaman tidak berbeda nyata.

\section{KESIMPULAN}

Respon tanaman cabai merah (Capsicum annuum L.) dan cabai rawit (Capsicum frutescens L.) pada parameter pertumbuhan dan produksi menunjukkan respon linier. Artinya, kebutuhan air tanaman cabai merah (Capsicum annuum L.) dan cabai rawit (Capsicum frutescens L.) masih lebih tinggi dibandingkan dengan perlakuan tingkat irigasi tertinggi yang diberikan pada percobaan ini yaitu $5 \mathrm{kc}$.Eo. 


\section{SARAN}

Pada penelitian selanjutnya dapat ditambahkan taraf perlakuan tingkat irigasi lebih besar dari $5 \mathrm{kc}$.Eo, sehingga dapat ditentukan kebutuhan air optimumnya.

\section{DAFTAR PUSTAKA}

Allen, R.G., L.S. Pereira, D. Raes, M. Smith. 1998. Crop Evapotranspiration (Guidelines for Computing Crop Water Requirements) Paper 56. Rome (IT): FAO Irrigation and Drainage Paper.

Alviana, V.F., A.D. Susila. 2009. Optimasi dosis pemupukan pada budidaya cabai (Capsicum annuum L.) menggunakan irigasi tetes dan mulsa polyethylene. $\mathrm{J}$ Agron. Indonesia. 37(1): 28-33.

Antony, E., R.B. Singandhupe. 2004. Impact of drip and surface irrigation on growth, yield and WUE of capsicum (Capsicum annиum L.). Agricultural Water Management. 2(65): 121-132.

Cafer, G., E. Iran, K. Akincik, S. Ucan, S.G. Akinci. 2006. Response of red hot pepper plant (Capsicum annuumL.) to the deficit irrigation. Akdeniz Uuniversiteisi Zirrat Fakultesi Dergisi. 19: 131-138.

[Dirjen Hortikultura] Direktorat Jenderal Hortikultura Kementerian Pertanian. 2015. Statistik Produksi Komoditas Sayur. http://www.hortikultura.pertanian. go.id. [15 September 2015].

Doorenbos, J., A.H. Kassam. 1979. Yield response to water irrigation, FAO irrigation and drainage Paper 33. Rome (IT): Food and Agriculture Organization of the United Nations.

[FAOSTAT] Food and Agricuture Organization of The United Nations. 2015. Countries by commodity: Top Production Chillies and Peppers, Green 2010-2012. http://faostat3.fao.org. [22 Februari 2016].
Fauziah, R., A.D. Susila, E. Sulistyono. 2016. Budidaya bawang merah (Allium ascalonicum L.) pada lahan kering menggunakan irigasi springkel pada berbagai volume dan frekuensi. J. Hort. Indonesia. 7(1):1-8.

González, D.V., F. Orgaz, E. Fereres. 2007. Responses of pepper to deficit irrigation for paprika production. Scientia Horticulturae.114: 77-82.

Juan-juan, Z., P. Qiang, L. Yin-li, W. Xing, H. Wang-lin. 2012. Leaf gas exchange, chlorophyll fluorescence, and fruit yield in hot pepper (Capsicum annuиm L) grown under different shade and soil moisture during the fruit growth stage. $\mathbf{J}$ of Integrative Agriculture. 11(6): 927937.

Kurnia, U. 2004. Prospek pengairan pertanian tanaman semusim lahan kering. Balai Penelitian Tanah. J. Litbang Pertanian. 23(4): 130-138.

Liu, H., H. Yang, J. Zheng, D. Jia, J. Wang, Y. Li, G. Huang. 2012. Irrigation scheduling strategies based on soil matric potential on yield and fruit quality of mulched-drip irrigated chili pepper in Northwest China. Agricultural Water Management. 115: 232-241.

Loizzo, M.R., A. Pugliese, M. Bonesi, F. Menichini, R. Tundis. 2015. Evaluation of chemical profile and antioxidant activity of twenty cultivars from Capsicum annum, Capsicum baccatum, Capsicum chacoense and Capsicum chinense: A comparison between fresh and processed peppers. Food Science and Technology. 64: 623-631.

Miranda, F.R., R.S. Gondim, C.A.G. Costa. 2006. Evapotranspiration and crop coefficients for tabasco pepper (Capsicum frutescens L.). Agricultural Water Management. 82:237-246.

Rameswaran, P., A. Tepe, A. Yazar, R. Ragab. 2016. Effect of drip-irrigation regimes with sline water on pepper productivity and soil salinity under greenhouse 
conditions. Scientia Horticulturae. 199: 114-123.

Shongwe, V.D., B.N. Mangongo, M.T. Masarirambi, A.M. Manyatsi. 2010. Effect of irrigation misture regimes on yield and quality of paprika (Capsicum aпnиит L). Physics and Chemistry of the Earth. 35: 717-722.

Sulistyono, E., Indriati. 2011. Pengaruh frekuensi irigasi dan waktu pemberian air terhadap pertubuhan dan produksi kencur (Kaempferia galangal L.). J. Agrovigor. 4(2): 105-111.
Sulistiyono, E., A.E. Juliana. 2014. Irrigation volume based on pan evaporation and their effects on water use efficiency and yield of hydroponically grown chilli. J of Tropical Crop Science. 1(1): 9-12.

Ucan, K., F. Killi, C. Gencoglan, H. Merdun. 2007. Effect of irrigation frequency and amount on water use efficiency and yield of sesame (Sesamum indicum L.) under field conditions. Field Crops Research. 101(3): 249-258. 